\title{
Resistivity Characterisation of Shallow Stratigraphy in Delineating Shell Midden at Guar Kepah, Penang, Malaysia
}

\author{
Najmiah Rosli, ${ }^{1}$ Nur Azwin Ismail, ${ }^{1 *}$ Hafizuddin Mansor $^{1}$ and Mokhtar Saidin ${ }^{2}$ \\ ${ }^{1}$ Geophysics Section, School of Physics, Universiti Sains Malaysia, \\ 11800 USM Pulau Pinang, Malaysia \\ ${ }^{2}$ Centre for Global Archaeological Research, Universiti Sains Malaysia, \\ 11800 USM Pulau Pinang, Malaysia \\ ${ }^{*}$ Corresponding author: nurazwin@usm.my
}

Published online: 25 April 2019

To cite this article: Rosli, N. et al. (2019). Resistivity characterisation of shallow stratigraphy in delineating shell midden at Guar Kepah, Penang, Malaysia. J. Phys. Sci., 30(1), 99-110, https://doi.org/10.21315/jps2019.30.1.8

To link to this article: https://doi.org/10.21315/jps2019.30.1.8

\begin{abstract}
Good stratigraphy mapping of a site is essential in archaeological explorations but Guar Kepah, Penang, Malaysia had no detailed subsurface mapping done previously up till now. As many archaeological remnants in the vicinity have an affiliation with shell middens, better understanding on Guar Kepah's strata will increase the efficiency of uncovering the shell middens while also saving a huge amount of energy in excavating. This research aims to distinguish Guar Kepah's buried shell midden from the surrounding strata using electrical resistivity method. The study area is composed of three shallow strata of unconsolidated soil with low resistivity values. The sandy-clay layer has the lowest resistivity $(<40 \Omega \mathrm{m})$, followed by densely packed shell layer (40-70 $\mathrm{\Omega m}$ ) and sandy layer (> $70 \Omega \mathrm{m}$ ). The presence of shells indicates that the uppermost strata is of marine origin, which automatically makes Gula Formation the youngest formation in Guar Kepah due to the absence of terrestrial deposits (Beruas Formation) on top of the layer. The shell layer from the resistivity profiles suggests that the layer has relatively uniform thickness throughout the site. The layer also becomes undulating and shallow towards the south (dipping), making the top sandy-clay soil become thinner or absent in the south. The dipping feature of the shell layer acts as an indicator that Guar Kepah used to be a beach ridge during sea transgression, and further proves that the area was once a marine environment. However, the shell layer at the southern zone poses an anomaly where it suddenly dips toward the centre. As a result, two zones were marked as potential shell middens at the south-western zone (only exhibits one side of the midden that is dipping towards centre) and south-eastern zone (shell midden elongated to the east). Subsequent excavation based on this study had successfully exposed the south-eastern midden and
\end{abstract}


proved that resistivity method could be used not only in stratigraphy identification, but also in characterising shell layer and detecting shell midden.

Keywords: Guar Kepah, shell midden, stratigraphy, Gula Formation, Beruas Formation

\section{INTRODUCTION}

Hanson reported that archaeology has long been adopting the laws of stratigraphy to define, interpret and understand the history of a site. ${ }^{1}$ Meanwhile, Harris expressed that stratigraphy is concerned about the relationship between fossils and strata or the specific aspect of the interface between strata. ${ }^{2}$ Previous studies at Guar Kepah since 1851 by British archaeologists had exposed many prehistoric remnants and human remains during excavation on shell middens. However, little study has been done on Guar Kepah stratigraphy, especially on its geophysical properties.

This study aims to characterise the shell layer in Guar Kepah using 2-D resistivity method in order to understand its prehistoric environments and to increase efficiency in the subsequent excavation works as a good understanding of the strata is at hand. Shell layer is highly associated with shell midden due to prehistoric civilisation's burial ritual, where the deceased were buried under a dome-shaped shell mound. The results can be used in guiding subsequent excavation works in the area and will also be used by engineers in the construction of a gallery. The results from this study can also be a guideline for future excavations of other sites with similar environment.

\section{EXPERIMENTAL}

\subsection{Study Area}

The study area is located at Kampung Guar Kepah in Seberang Perai, Penang, Malaysia as shown in Figure 1. Surrounded by paddy fields, the site is about $50 \mathrm{~m}$ from the main road and $8 \mathrm{~km}$ from the present coast line, while the current Muda River is only $0.5 \mathrm{~km}$ at its north from the site. A house used to overlie the site before being demolished for archaeological activities. Previous archaeological study done here had discovered ceramic artefacts, "sumatralite" unifacial and bifacial pebble tools which indicate that the site belongs in Early Neolithic period. ${ }^{3}$ The shell samples from their research also suggest that Guar Kepah was inhabited about 5000-6000 years ago. 


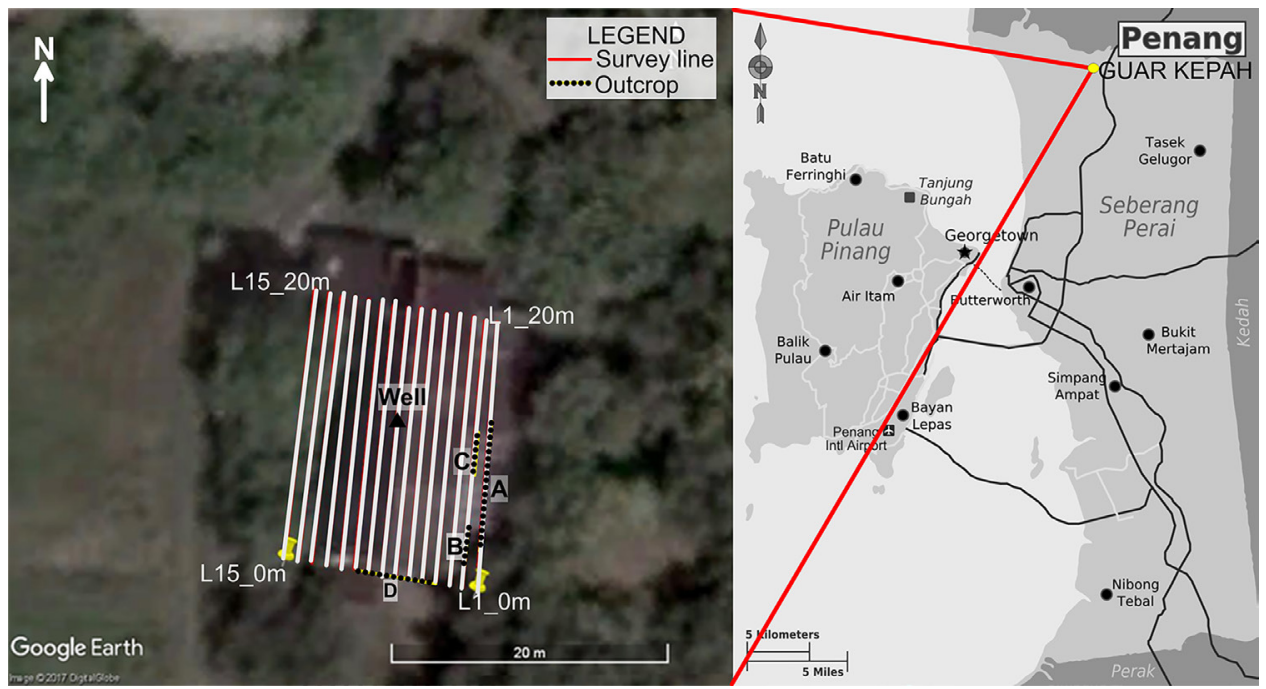

Figure 1: Location of the study area, outcrops and the survey lines starting from Line 1 (L1) until Line 15 (L15).

\subsection{Geology}

According to Tjia, Guar Kepah was situated on Muda River banks and high up on stranded beach ridges which was deposited around mid-Holocene during a sea transgression $4000-5000$ years ago. ${ }^{4}$ Close proximity to both sea and river made the area strategic for food collection. The coastal areas of Seberang Perai are underlain by Simpang Formation, Gula Formation and Beruas Formation of Quaternary period as shown in Table 1. The Simpang Formation is the oldest Quaternary formation, followed by the Gula and Beruas Formations according to Hassan. ${ }^{5}$

Table 1: Quaternary stratigraphy of Seberang Perai, where Beruas Formation is overlain on top of Gula and Simpang Formations respectively modified from Hassan. ${ }^{5}$

\begin{tabular}{|c|c|c|c|}
\hline \multirow{4}{*}{ 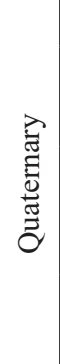 } & Epoch & Formation & Lithology \\
\hline & Holocene & $\begin{array}{l}\text { Beruas } \\
\text { (Young Alluvium) }\end{array}$ & $\begin{array}{l}\text { Clay, silt, sand, gravel, locally, minor peat } \\
\text { intercalations deposited in terrestrial environment }\end{array}$ \\
\hline & & Gula & $\begin{array}{l}\text { Clay, silt, sand and minor amount of gravel and } \\
\text { shells deposited in mangrove and/or marine } \\
\text { environment }\end{array}$ \\
\hline & Pleistocene & $\begin{array}{l}\text { Simpang } \\
\text { (Old Alluvium) }\end{array}$ & $\begin{array}{l}\text { Clay, silt, sand, gravel and locally minor amount of } \\
\text { peat deposited in terrestrial environment }\end{array}$ \\
\hline
\end{tabular}




\subsection{Methodology}

Geophysical method employed for this study was 2-D electrical resistivity method as it could differentiate the presence of archaeological features with the surrounding soil. The survey was done using a multi-electrode resistivity meter system (ABEM SAS4000) which were laid out in a straight line with a constant spacing of $0.5 \mathrm{~m}$ between electrodes for high resolution. Wenner-Schlumberger electrode array was chosen due to its high sensitivity to both lateral and vertical changes. A computercontrolled system was then used to automatically select the active electrodes for each measurement as described by Griffiths and Barker. ${ }^{6}$ Fifteen parallel lines of $20 \mathrm{~m}$ length each were carried out with a separation distance of $1 \mathrm{~m}$ between each survey line as shown in Figure 1. This specification was chosen in order to cover the survey area precisely. Analysis of the obtained data was done using a microcomputer with reference to Table 2 which shows resistivity values of common soil obtained from Keller and Frischknecht. ${ }^{7}$ Data from RES2DINV inversion was extracted to plot a shell layer map in Surfer software which gave flexibility in data processing and presentation. The data was later confirmed by cross-referencing with exposed stratigraphy at the site due to construction works of the gallery.

Table 1: Resistivity values of common soil modified from Keller and Frischknecht. ${ }^{7}$

\begin{tabular}{lc}
\hline Soil & Resistivity $(\Omega \mathrm{m})$ \\
\hline Alluvium & $10-800$ \\
Clay & $1-100$ \\
Sand & $60-1,000$ \\
Groundwater & $10-100$ \\
\hline
\end{tabular}

\section{RESULTS AND DISCUSSION}

Figure 2 shows resistivity profiles of Lines $1-3$. Profiles of Lines 4-15 are shown in Appendix. The subsurface profiles distinctly show bedding planes characteristic which is a common sedimentary feature. The low resistivity values of $<2000 \Omega \mathrm{m}$ suggest that the area is made up of unconsolidated soil. The shallow subsurface was further categorised into three strata, where the shell layer is sandwiched between sandy-clay soil on top and sandy soil underneath. The uppermost layer is moist sandy-clay with resistivity values of $<40 \Omega \mathrm{m}$, followed by moist shell layer of 40-70 $\Omega \mathrm{m}$, and dry sandy layer of $>70 \Omega \mathrm{m}$. The shell layer is densely packed with shells in sandy-clay soil as shown in Figure 3. 

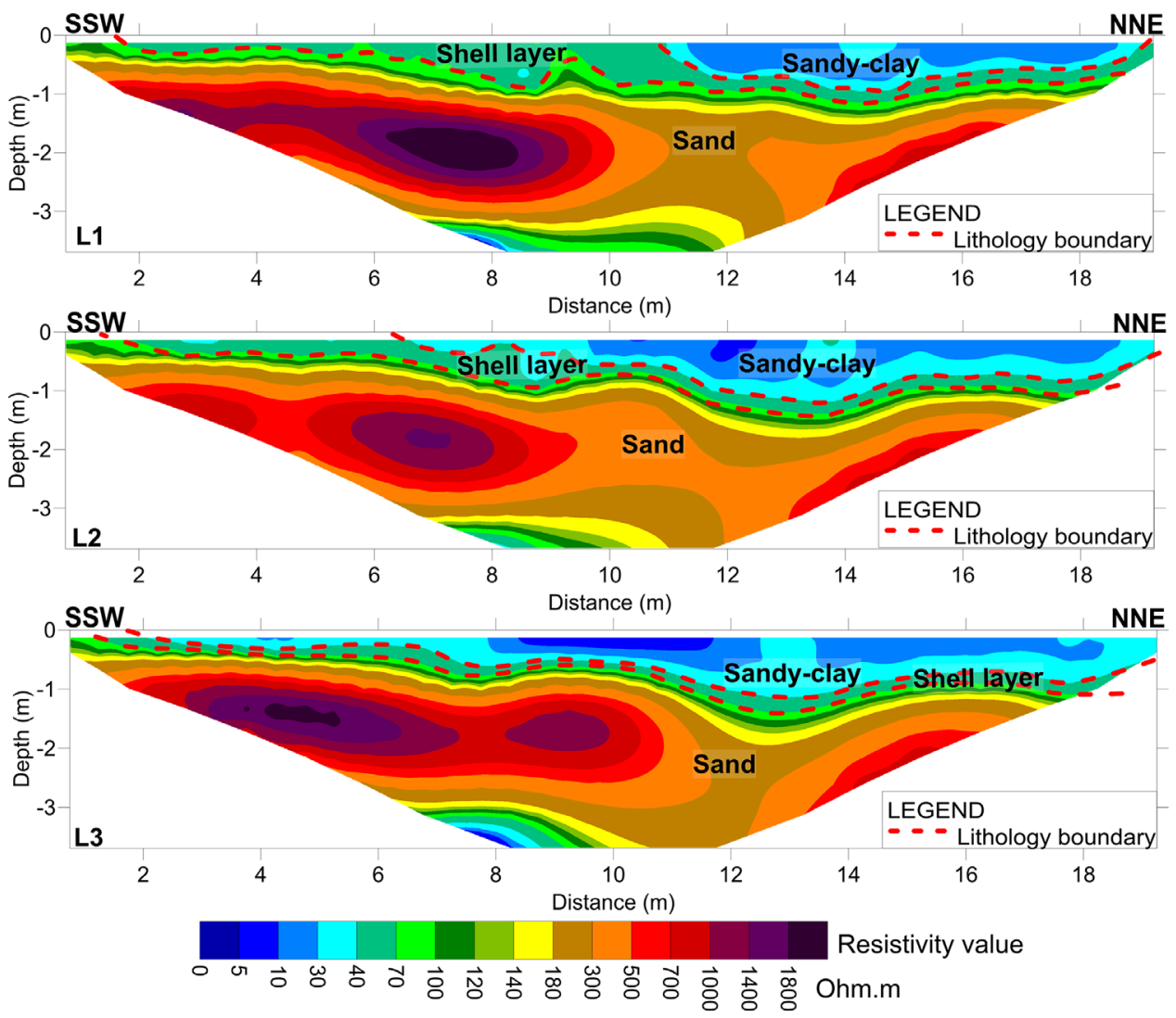

Figure 2: Resistivity profiles of Lines $1-3$.

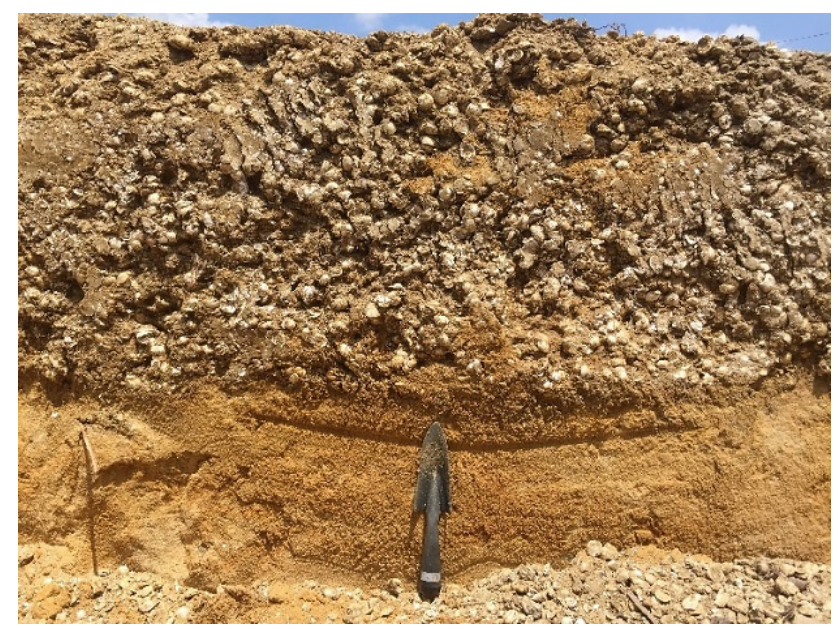

Figure 3: Compacted shell layer in sandy-clay soil overlying sandy layer. 

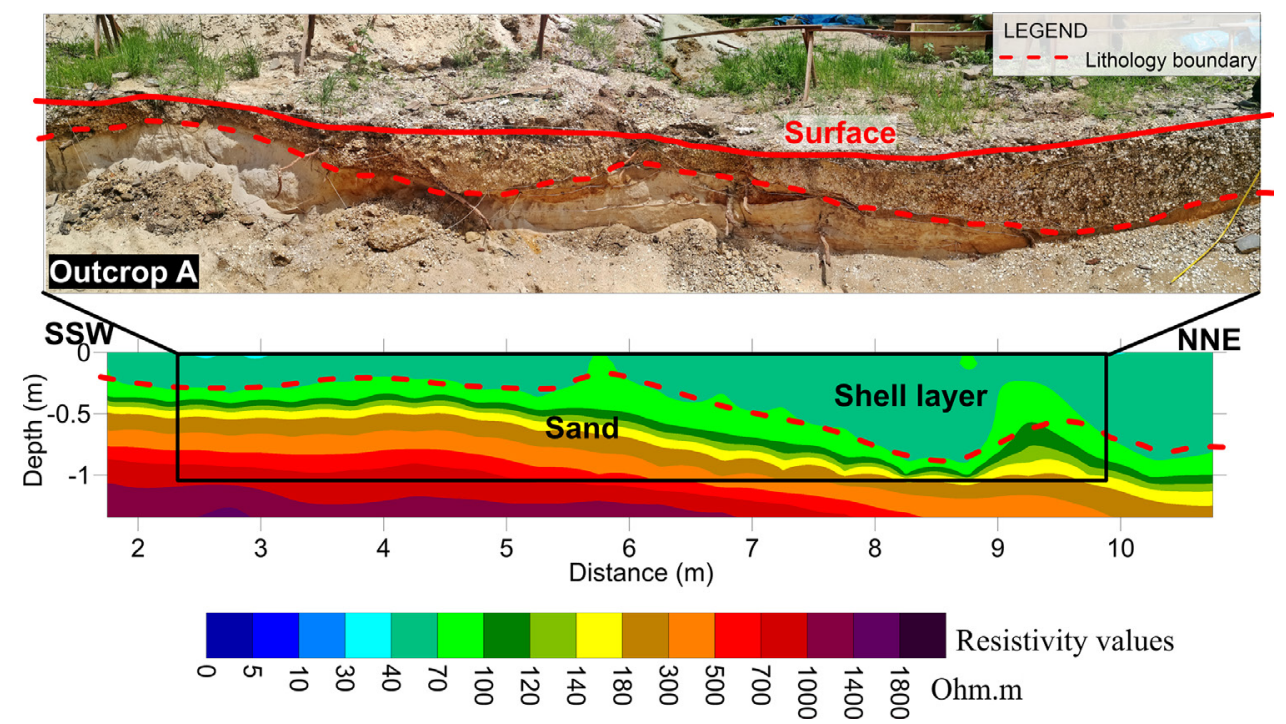

Figure 4: Correlation of resistivity profile Line 1 with in-line exposed stratigraphy (outcrop A).

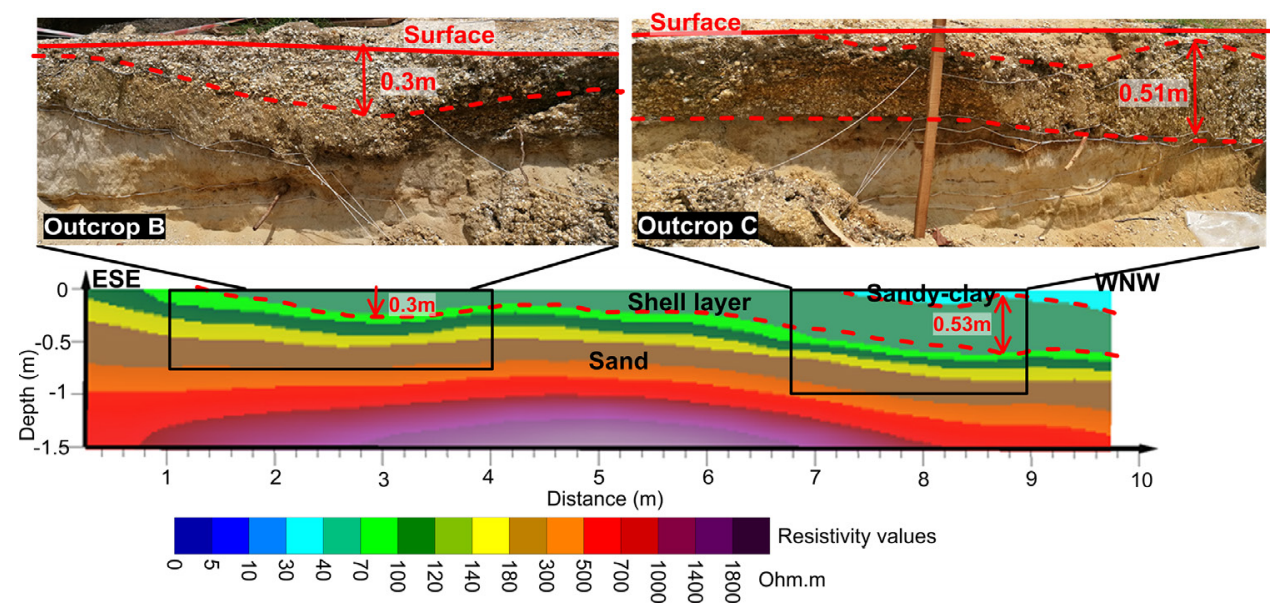

Figure 5: Correlation of resistivity profile of Line 2 with excavated in-line stratigraphy (outcrops B and C).

The results were later correlated with exposed stratigraphy (outcrops) due to the gallery construction and showed that the range of resistivity values of each layer are consistent with the stratigraphy. Figure 4 shows correlation of outcrop A which is lying on Line 1 at distance 2.3-9.7 $\mathrm{m}$ while Figure 5 are outcrops B and C lying on 
Line 2. Figure 6 shows the correlation of outcrop $\mathrm{D}$ with resistivity profile cutting across Lines 3-10, at distance $0 \mathrm{~m}$. The resistivity profiles suggest that most of the southern parts of the shell layer are exposed on the surface while the upper sandyclay soil is thin or absent as the shell layer is shallowing southwards, and this was validated with the exposed stratigraphy. The profiles also detected a sudden downward dipping of layers at the southern part of the study area going towards the centre, an anomaly compared to the rest of the area as shown in Figure 6.

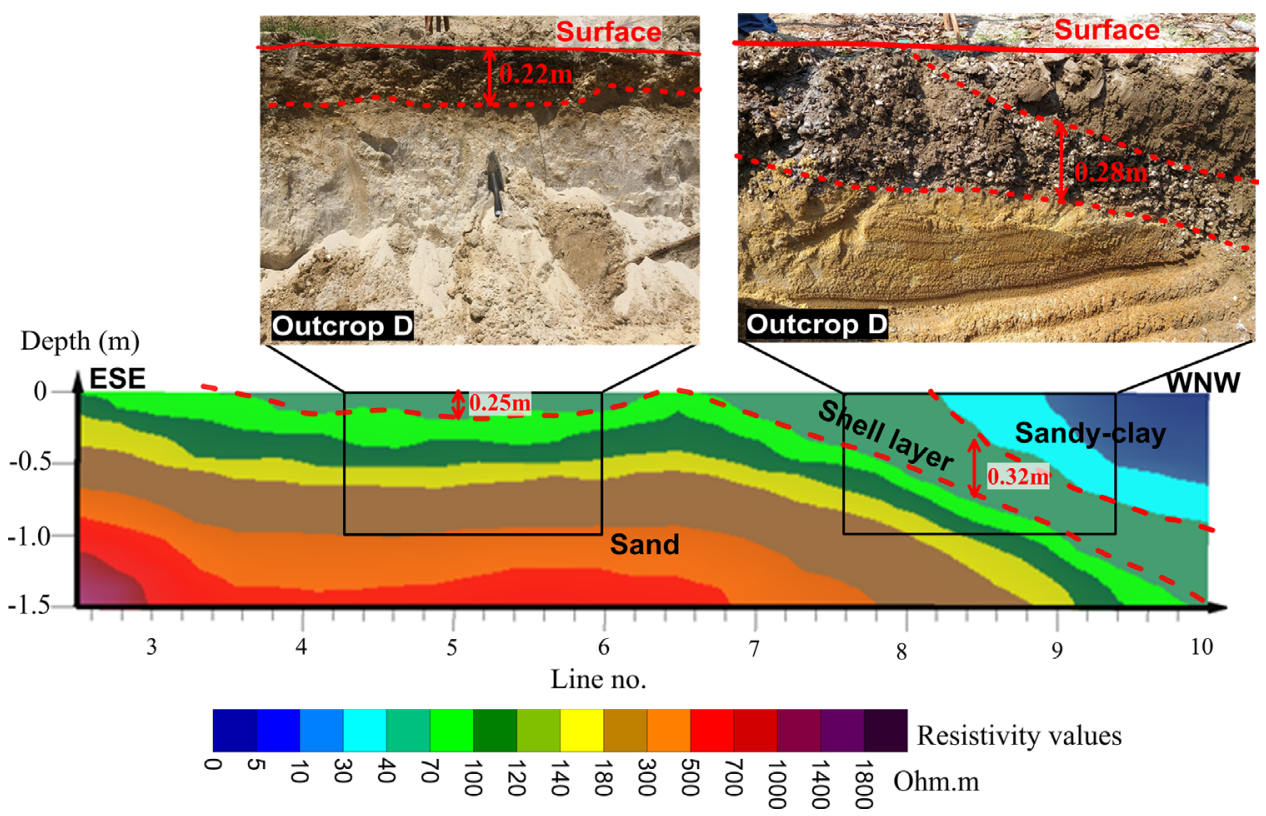

Figure 6: Correlation of resistivity profile cutting across of Lines 3-10 with excavated in-line stratigraphy (outcrop D).

In terms of the shell layer thickness, Figures $7(\mathrm{a}$ and $\mathrm{b})$ show the upper and lower boundaries of the shell layer profiles. The thickness can be seen in Figure 7(c), where it ranges from $0.20-0.30 \mathrm{~m}$, but thickens up to $0.72 \mathrm{~m}$ at the eastern zone. The layer is also undulating and has different depths, with the deepest depth found to be $1.3 \mathrm{~m}$ from the ground surface to the upper boundary of the shell layer. The shell layer profile also shows the depth to the shell layer at the southern part is abnormally shallower than the rest of the site. These anomalies of the layers at the southern zone mimic a mound, hence the zone was marked as a potential zone for shell middens. The south-western potential midden could be the side of a mound that is dipping downwards whereas the south-eastern potential midden is elongated eastward. 

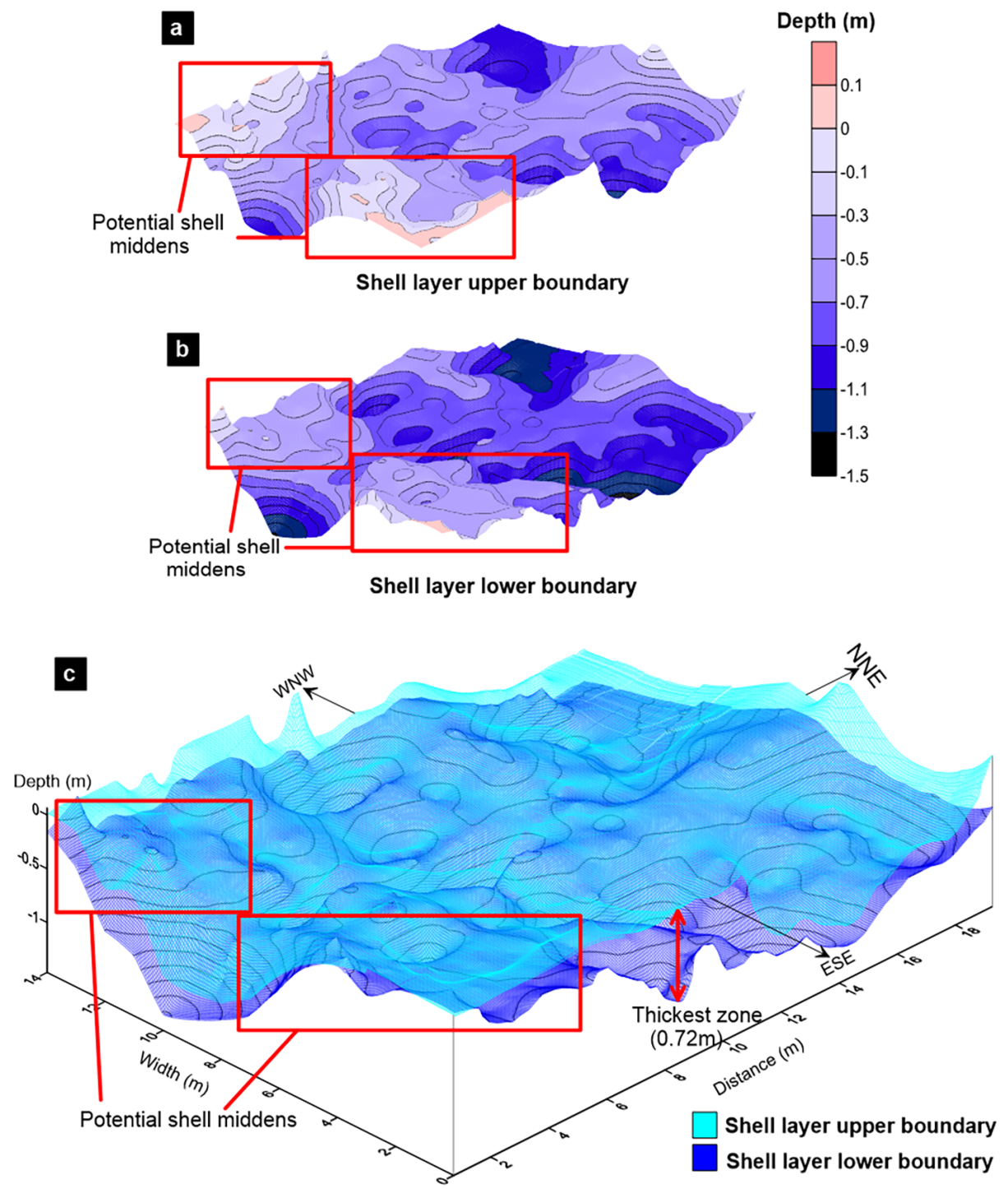

Figure 7: Topography of shell layer where (a) is the individual upper boundary, (b) is the individual lower boundary, and (c) is the combined boundaries of upper and lower shell layer.

During excavation, one of the potential shell midden was exposed and thus proved its existence at the south-eastern part of the site as shown in Figure 8. The shell midden was distinguished from the natural shells stratum based on the change of the shell layer morphology seen from resistivity results, where the shell midden is dome-shaped whereas the naturally deposited shell layer is planar. The location 
of the midden complements the predicted shell midden, and further justifies that resistivity method can be used to characterise shell layer and distinguish the shell midden from the surrounding strata. Even though the shell midden's resistivity values are similar to the shell layer, the contrast between the shell layer and its surrounding helped in the initial steps of identifying the middens and was further resolved by the sudden changes in the subsurface topography of the shell layer.

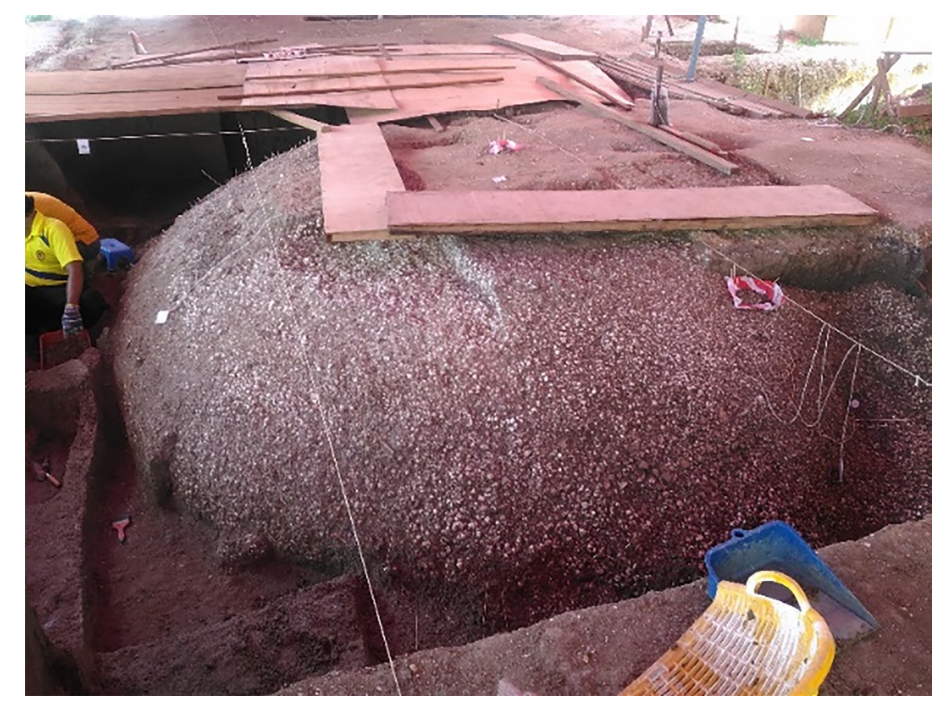

Figure 8: Excavated shell midden at south-eastern part of site.

In terms of geology, the presence of shells indicates that the soil originated from marine environment and is part of Gula Formation. The dipping of the strata also suggests that the area was located on a stranded beach ridge as Tjia had suggested, further proving that Guar Kepah had once experienced marine environment during sea transgression. The absence of terrestrial deposits implies that Beruas Formation is absent in Guar Kepah and that makes Gula Formation the youngest formation in this area.

\section{CONCLUSION}

The stratigraphy of the study area is composed of three layers of unconsolidated soil with low resistivity values. The uppermost layer is sandy-clay, followed by densely compacted shell layer and sandy layer. The presence of shells indicates that the uppermost strata in the area are made of Gula Formation, a marine origin environment. The absence of terrestrial deposits (Beruas Formation) on top of Gula Formation shows that Gula Formation is the youngest formation in the vicinity. 
The resistivity values of the strata increase from top to bottom, with sandy-clay layer having the lowest resistivity $(<40 \Omega \mathrm{m})$, followed by shell layer $(40-70 \Omega \mathrm{m})$ and sandy layer with the highest resistivity $(>70 \Omega \mathrm{m})$. The resistivity and shell layer profiles indicate that the shell layer has a thickness of $0.20-0.30 \mathrm{~m}$ which is undulating (0-1.3 $\mathrm{m}$ to the shell layer from surface) and has a trend of shallowing to the south, making the top sandy-clay layer thin or absent in the south. Dipping of the shell layer indicates that Guar Kepah used to be a beach ridge during sea transgression and had once experienced marine environment. However, a sudden downward dipping of the shell layer at the southern zone poses as an anomaly. Due to the anomalies of the shell layer that are shallowing and suddenly dipping at the south, two zones were marked as potential shell middens at the south-western and south-eastern zones.

Following the investigation, an excavation had exposed the south-eastern midden and proved that resistivity method is a powerful tool in subsurface mapping and can be used in archaeological exploration. As the shell midden resistivity values are similar to the shell layer, it is crucial to differentiate the shell layer from the surrounding soil. This can be resolved by looking at the subsurface topography change of the shell layer in identifying the middens. At the end of this study, the shallow stratigraphy of Guar Kepah was successfully characterised in terms of its formations, geophysical and geological properties with addition to the discovery of the prehistoric geomorphology of the area (coastal). With these detailed descriptions, prediction of shell midden location was highly facilitated.

\section{ACKNOWLEDGEMENTS}

A sincere gratitude is extended to the Centre for Global Archaeological Research (CGAR), Universiti Sains Malaysia (USM), Penang, for giving us the opportunity to conduct this study. We are also thankful to USM Short Term Grant 304/ PFIZIK/6315022 for the financial support. We would like to extend our appreciation to our colleagues for their continuous guidance and assistance. A special thanks to Geophysics lab assistant, Mr. Jamil Yusuf, without whom this study could not be completed.

\section{REFERENCES}

1. Hanson, I. D. (2004). The importance of stratigraphy in forensic investigation. Geol. Soc., 232(1), 39-47, https://doi.org/10.1144/GSL.SP.2004.232.01.06.

2. Harris, E. C. (1989). Principles of archaeological stratigraphy, 2nd ed. London: Academic Press, https://doi.org/10.1016/C2009-0-21688-6. 
3. Cullin, E. G. \& Zehnder, W. F. (1905). The early history of Penang, 1592-1827. London: Criterion Press.

4. Tjia, H. D. (1987). Ancient shorelines in Peninsular Malaysia. SPAFA Final Report, Seminar in Prehistory of Southeast Asia, Thailand, 239-257.

5. Hassan, K. (1990). A summary of the Quaternary geology investigations in Seberang Prai, Pulau Pinang and Kuala Kurau. Geol. Soc. Malaysia Bull., 26, 47-53.

6. Griffiths, D. H. \& Barker, R. D. (1993). Two-dimensional resistivity imaging and modelling in areas of complex geology. J. Appl. Geophys., 29(3), 211-226, https://doi.org/10.1016/0926-9851(93)90005-J.

7. Keller, G. V. \& Frischknecht, F. C. (1966). Electrical methods in geophysical prospecting. Oxford: Pergamon Press. 


\section{APPENDIX}
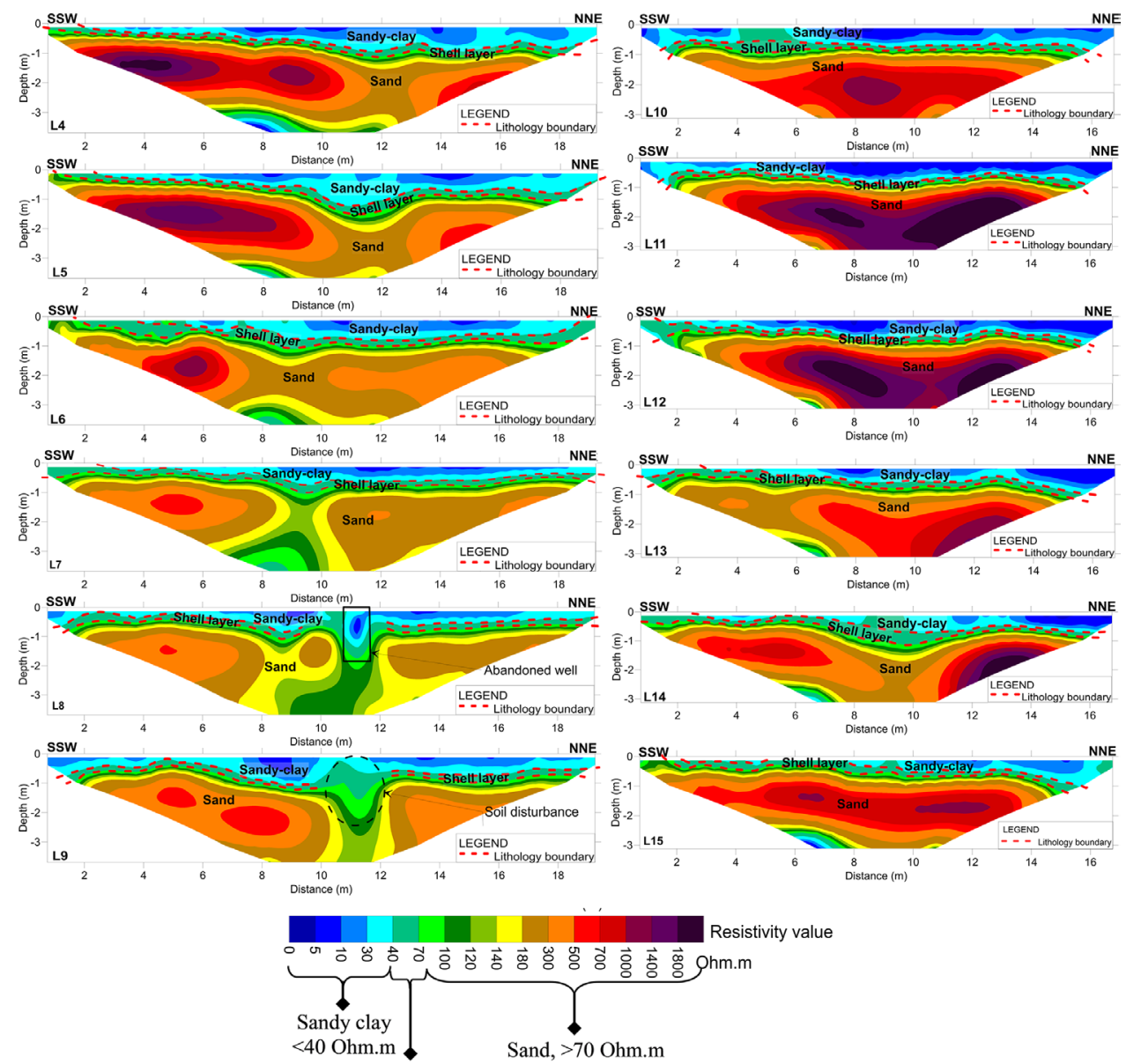

Shell layer

40-70 Ohm.m

Resistivity profiles of Lines 4-16 showing values for each layer. 